\title{
IGF2BP2 Gene
}

National Cancer Institute

\section{Source}

National Cancer Institute. IGF2BP2 Gene. NCI Thesaurus. Code C147849.

This gene plays a role in RNA transport and mRNA stability. 